\title{
A Review on the Ayurvedic Dietetic Principle w.s.r to Sapta Ahara Kalpana Visesha
}

\author{
${ }^{1}$ Dr.Dhruva Prasad, ${ }^{2}$ Dr. P.Sudhakar Reddy \\ ${ }^{1}$ III MD Scholar, Department of PG Studies in Swasthavritta, JSSAMC, Mysuru. \\ ${ }^{2}$ Professor and HOD, Department of PG Studies in Swasthavritta, JSSAMC, Mysuru.
}

\begin{abstract}
:-
Food is an important component of human life. We cannot imagine a life without food. Ayurveda has given utmost importance to food. Ahara is considered as one among the trioupasthambas according to Acharya Charaka ${ }^{1}$. It is mentioned first as it is the most important for the sustenance of life. Sapta ahara kalpana vishesha is a dietetic concept explained in Ashtanga Sangraha ${ }^{2}$. It encompasses seven principles of food intake which is unique in itself. By following this principle one can not only prevent diseases but it also helps to maintaining the good health
\end{abstract}

Key words - Ahara, Pathya, Kalpana, Health.

\section{Introduction}

The most important component for the sustenance of human life is food. All the living beings are dependent on it. Every human being wishes to live a long life without any disease. Food helps in the complete growth and development of an individual. The right kind of food is the single most important factor in the growth and development. Improper food habits have lead to many disease conditions. Disease free condition is the best source of virtue, wealth, gratification whereas diseases are the destroyer of the same $\mathrm{s}^{3}$. Thus in the perspective of promotion of health and prevention of diseases ayurveda has given utmost importance to food. Ahara is considered one among the trioupasthambas. Among them it is mentioned first as it is most important for the sustenance of life. Food has been considered sacred and was worshipped since the Vedic period ${ }^{4}$. Food was considered as Brahma and man is considered as the essence of food in the Taittareya Upanishad ${ }^{5}$. Pure foods lead to the purity of the mind as said in Chandogya Upanishad ${ }^{6}$. Sapta Ahara Kalpana Vishesha is a beautiful concept explained by Ashtanga Sangraha in the Annapana vidhi adhyaya ${ }^{7}$.

\section{Aims and Objectives}

1. To understand the concept of Sapta Ahara Kalpana Vishesha conceptually

2. To understand the role of the principle of Sapta Ahara Kalpana Vishesha and its significance in present era towards maintaining a good health.

\section{Materials and Methods}

Literature search- The literature review of Sapta Ahara Kalpana Vishesha is taken from the classical texts of Ayurveda.

Type of Study - Fundamental Study - Literary Study on Sapta ahara kalpana Vishesha and its role in health promotion and disease prevention.

Sapta Ahara Kalpana Vishesha consists of seven factors of dietetics which consist of Swabhava, Samyoga, Samskara, Matra, Desha, Kala and Upayoga Vyavastha ${ }^{8}$.

\section{Svabhava}

Svabhava means the nature of the food. It is also called as prakruti according to acharya charaka ${ }^{9}$. By the ahara svabhava, divyodaka (rain water), rakta shali (red rice), shastika shali (variety of rice), mudga (green 
${ }^{1}$ Dr.Dhruva Prasad , International Journal of Ayurvedic \& Herbal Medicine 8(4) July.-August. 2018 (3296-3299)

gram), ena (deer), lava (sparrow), are laghu (light) and easy to digest whereas kshira (milk), ikshu(sugarcane), vrihi (form of rice), masha (black gram), anupa mamsa(aquatic meat), are considered to be heavy and are not easily digestible ${ }^{10}$. The most important characteristic feature is that the svabhava of the food stuffs can be altered by subjecting to various processing as described further.

\section{Samyoga}

Samyoga is the mixing of two or more substances together. This union produces special effects not present in individual substances ${ }^{11}$.

\section{Samskara}

Samskara is the result of toyagni sannikarsha (contact with water and fire), shoucha (washing), manthana (churning), desha (place), kala (time), bhavana (trituration), bhajana(vessel) $)^{12}$

\section{Matra}

Matra is the quantity of food consumed. It is applicable to the panda parimana (total quantity of food to be consumed) and pratyeka dravya parimana (quantity of individual items) $)^{13}$

\section{Desha}

Desha refers to both where the food is grown and where the upayokta (user) lives. Upayokta is the one who consumes the food. He is of two types- Swastha (healthy) and atura(diseased) ${ }^{14}$.

\section{Kala}

Kala refers to both the season and the stage of disease and also signs of proper digestion and improper digestion. Food which is partaken long after the usual time will cause obstruction to movement of vata, undergoes digestion with difficulty, makes the body weak and destroys the desire for food ${ }^{15}$.

\section{Upayoga vyavastha}

Upayoga vyavastha is the manner of taking food. Persons should not take food without taking bath, without putting on any clothes, without offering oblations to fire, without repeating the holy hymns, without offering to gods, without giving food first to the fire, preceptors, the invited and uninvited guests, dogs, birds, beggars, to those depending upon him and others who depend on them and animals like cows, horse, etc maintained in the house. Person must partake food from his own hand, at a suitable place, time and accompaniments, wearing garlands and ornaments, with scents anointed to the hands and feet, his face and mouth well cleaned, helped by the affectionate, food not being contaminated by hairs or flies, he should not abuse the food, food which is not used by others, not made hot for the second time, not very hot, overcooked, one should not consume the foods he is not accustomed to or which is unknown. It should not be taken late in the evening nor very early in the morning. Foods must not be consumed in an open place or in sunlight, darkness, lying in bed, under a tree, one should also not consume food in an broken vessel, or the one which is not covered or which is not clean, one should also not consume by holding the container or food in hand. The person should eat food facing east and with purity of mind, served by clean and affectionate, unhungry obedient people and that food suitable to him. Foods which are preserved from the previous day should not be taken except curds, honey, ghee, liquid fo0ds containing flour, soured whey and pudding prepared from milk. Food should contain fats and must be easily digestible and warm. It should not be eaten very leisurely or very hurriedly or accompanied with too much of talk or laughter. The person should eat food with relish and with a good knowledge of his own-self ${ }^{16}$.

\section{Discussion}

Food is a important component of human life. Our health is completely dependent on the food we consume. To maintain a good health it is very important to follow a balanced diet ${ }^{17}$. In the modern dietetics we can see that the qualitative aspect of food substances are being given more significance like proteins, carbohydrates, fats, vitamins, minerals and in terms of calories ${ }^{18}$. The source of the food, its innate property, method of cooking, the effect of various food combinations, quantity of food stuffs, place of origin of food stuffs and the place of consumption, time of consumption are not being given its due importance whereas the concept of Sapta Ahara Kalpana Vishesha, which was written centuries ago gives much importance to the various factors of dietetics. Thus it would be fine to say that only assessing the foods only based on its nutritional contents are not enough, various other factor factors also play a crucial role in the maintenance of health. The concept of Sapta Ahara Kalpana Vishesha is said to be inspired from the concept of Asta Ahara Vidhi 
Vishesha Ayatana of charaka. The main difference among the both is that the former does not include upayokta as a separate entity like the latter. It considers upayokta is a part of desha. In the charaka samhita, svabhava is considered as prakruti. Here in Ashtanga sangraha, samyoga is explained next to swabhava whereas in Asta Ahara Vidhi Vishesha Ayatana of charaka samhita we find that samskara is called as karana, which is explained next to prakruti followed by samyoga. Here in both the texts swabhava and prakruti has been explained very beautifully. Swabhava or nature of the food stuffs is important as one can make a choice of his food stuff based on the power of digestion. Once one eats according to his digestive capacity he will be free from diseases ${ }^{19}$. Samyoga is the combination of food stuffs. Samyoga is important in the context of dining and cooking of food as there are certain foods which are very much compatible with each other but there are certain foods which should not be cooked or consumed together. This knowledge is very important to prevent diseases. Here in Sapta Ahara Kalpana Vishesha, there is no much detailed elaboration of samyoga as to how we find in Ahara Vidhi Vishesha Ayatana of charaka. If foods of opposite properties are mixed together it is considered as viruddhahara ${ }^{20}$. Samskara is the processing of the food stuffs. Certain food stuffs may be heavy in nature and difficult to digest, so such foods by processing with water and heat becomes easier for digestion. By applying the knowledge of samskara we can change the property of food stuffs according to our convenience. For example we can make a light food heavy by samskara and in the similar way heavy foods to light by repeated washing, cooking etc. Matra is the quantity of foods stuffs which is the quantity of the entire food consumed and the quantity of individual food items. Even Charaka has explained two types which are Sarvagraha and Parigraha ${ }^{21}$. Matra is important factor to consider while consuming food. If one eats insufficiently as per his needs then there is a gross increase of Vata dosha in the body if one consumes excessively than his limits then the food will not get properly digested or it will be digested slowly and it vitiates all the three Doshas. One must therefore take efforts to eat in the right quantity. Desha is the place where the food stuff grows and where the consumer lives. The place or the source of the food is also be considered as there is variation in the property of food stuffs from place to place. The place where the person consumes food is also to be considered. One should also ensure that one must eat at the right time and as per the season to maintain a good health. Finally one should follow all rules and regulations of dietetics to maintain a good health.

\section{Conclusion}

In this present era we can see that there is an increase in the non communicable diseases world-wide. The major cause for the same is poor dietary habits and poor lifestyle. Modern dietary habits include junk foods, fast foods, high calorie foods, carbonated drinks and processed foods like deep fried foods which are not good for the health. Most of the people are suffering from osteoporosis, malnutrition, anaemia, obesity, diabetes, and hypertension. It is the need of the hour to create awareness and educate the people regarding the concept and methodology of proper food selection, preparation, and food intake as enshrined in the classical ayurvedic principles like Sapta Ahara Kalpana Vishesha and Asta Ahara Vidhi Vishesha Ayatana.

\section{References}

1. Sharma P.V. Charaka Samhita: Vol I: Varanasi: Chaukhambha Orientalia;First Reprint 2011. p 75

2. Murthy, Sreekantha. Astanga Sangraha: Vol1: Varanasi: Chaukhambha Orientalia; Ninth edition. 2005. p 226

3. Sharma P.V. Charaka Samhita: Vol I: Varanasi: Chaukhambha Orientalia;First Reprint 2011. p 4

4. Griffith, Ralph Thomas Hotchkin. The Hymns of the Rigveda. Benares: E.J Lazarus and Co; 1920

5. Sankarachaya. The Taittiriya Upanisad. Second edition. Holenarasipura: Adhyatma prakasha karyalaya; 2011. p 319

6. Krishnananda,Swami. The Chhandogya Upanishad. First edition. Rishikesh: The Divine Life Society; 1984. p254.

7. Murthy, Sreekantha. Astanga Sangraha: Vol1: Varanasi: Chaukhambha Orientalia; Ninth edition. 2005. P226

8. Sharma P.V. Charaka Samhita: Vol I: Varanasi: Chaukhambha Orientalia;First Reprint 2011. p 305

9. Murthy, Sreekantha. Astanga Sangraha: Vol1: Varanasi: Chaukhambha Orientalia; Ninth edition. 2005. p 227 
${ }^{1}$ Dr.Dhruva Prasad , International Journal of Ayurvedic \& Herbal Medicine 8(4) July.-August. 2018 (3296-3299)

10. Murthy, Sreekantha. Astanga Sangraha: Vol1: Varanasi: Chaukhambha Orientalia; Ninth edition. 2005. p 228

11. Murthy, Sreekantha. Astanga Sangraha: Vol1: Varanasi: Chaukhambha Orientalia; Ninth edition. 2005. p 229

12. Lakshmi, Sri. Food Science: Chennai: New Age Publishers: 5th Edition; 2015, p 37

13. Lakshmi, Sri. Food Science: Chennai: New Age Publishers: 5th Edition; 2015, p 37

14. Sharma P.V. Charaka Samhita: Vol I: Varanasi: Chaukhambha Orientalia;First Reprint 2011. p 32

15. Sabnis M. Viruddha Ahara: A Critical Review. Ayu Journal. 2012.33(3) 332-336.

16. Sharma P.V. Charaka Samhita: Vol I: Varanasi: Chaukhambha Orientalia; First Reprint 2011. p 306 